\title{
THE LECTIN IN THE SEEDS OF VICIA CRACCA L.
}

\section{A POPULATION STUDY AND A POSSIBLE FUNCTION FOR THE LECTIN}

\author{
DAVID A. JONES \\ Department of Genetics, University of Birmingham
}

Received 7.ii.64

\section{INTRODUCTION}

RENKonen and Therman (1952) discovered that the seeds of Vicia cracca $\mathrm{L}$. which contained the anti- $A$ lectin weighed between 8 and I $5 \mathrm{mg}$. and contained 14 or 28 chromosomes. The seeds with the nonspecific agglutinin weighed over $22 \mathrm{mg}$. and had $\mathrm{I} 2$ or 24 chromosomes. Rousi (196i) has subsequently shown that the 24 chromosome plants were Vicia tenuifolia Roth. while the 12 chromosome plants probably represent a middle to far east species even though the plants in Kew Gardens with $2 \mathrm{~N}=12$ were considered to be British in origin.

Before the publication of Rousi's work a population study of the lectin in the seeds of Vicia cracca was begun. From Renkonen and Therman (1952) it seemed that a plant producing seeds lighter than $22 \mathrm{mg}$. was more likely to contain I 4 or 28 chromosomes than 12 or 24 . Thus seed weight promised to be a useful character for distinguishing between the two chromosome series in wild populations of the plant. Verification of the chromosome number could be postponed until after the fruiting season.

Seeds were collected from plants growing in 89 populations in England and Wales and no seeds heavier than $22 \mathrm{mg}$. were found. One hundred and thirty-five seeds from $5^{2}$ plants growing in twelve populations were germinated and counts made of their root-tip chromosomes. The seeds from $5 \mathrm{I}$ of the plants all contained 28 chromosomes, although there was some evidence of aneusomaty. All twelve seeds from a plant growing at Llancynfelyn, Cardigan, contained 27 chromosomes. As the seeds did not all come from the same pod, it is likely that the seed parent was deficient in at least one and probably two chromosomes. Apart from this one plant there is no evidence that plants with chromosome numbers other than 28 have been sampled.

\section{THE POPULATION STUDY}

Earlier work (Jones, I $96 \mathrm{I}$ ) showed that an extract of one seed in I ml. of $0.15 \mathrm{M}$ saline gave a satisfactory concentration of lectin for assaying the content of individual seeds. For the present work M.R.C. pattern perspex tiles were used for the agglutination tests. The technique for testing seeds is very laborious and an automatic method would be necessary for a full population study. 
D. A. JONES

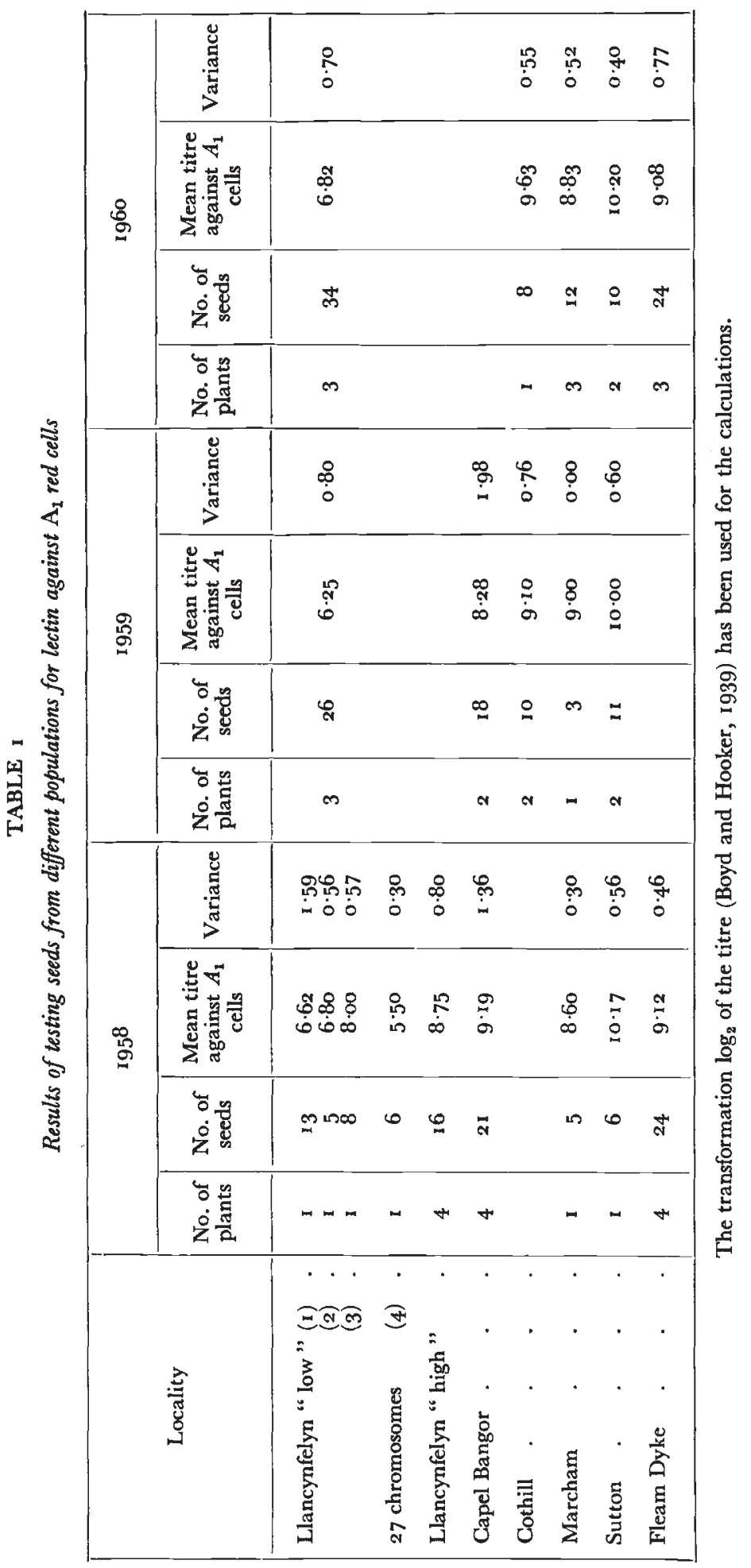


The seeds from each plant were put into a separate packet, so that it would be possible to test several seeds from the same plant and thus detect any variation within and between plants in the lectin content of seeds. The seeds obtained from seven colonies have been studied, being representative of western, central and eastern Britain. Seed samples were taken from as many of the colonies as it was possible to visit in the autumn of three successive years. Some of the colonies were sampled in only two of the three years. Most of the seeds ( 84 per cent.) weighed between I 3 and I $7 \mathrm{mg}$., while the range of weight was from I0.0 to I9.5 mg. The seed extracts were titrated against human $A_{1}$ red-cells within six months of harvesting.

\section{Results}

The results are presented in a condensed form in table I and the analyses are in tables 2, 3 and 4 . Vicia cracca is a perennial but plants

TABLE 2

Analysis of variance of the regression of seed weight on titre



do not flower in their first year when grown from seed. It is thus not possible to say whether the same plants have been sampled in successive years. Consistent variation in lectin titre from year to year in the same population may, therefore be due to two quite different causes: the same plants may have been sampled in successive years; or, if there is a high parent offspring correlation, indicating a large heritable component in the variation, then the population could be close to equilibrium. In the former case the measurements in successive years will be replicates with respect to the seed parent but not for the pollen parent, while in the latter case some or all of the plants will be progeny of mature plants present in the population at least two years previously.

Table 2 shows that, overall, there is no significant regression of seed weight on titre against $A_{1}$ red-cells which supports the conclusion drawn earlier (Jones, 1964 ). Of the $4^{1}$ plants whose seeds were tested for agglutinins only three gave a regression coefficient significantly different from zero at the 5 per cent. level. Obviously all the positive and all the negative regression coefficients of the other $3^{8}$ plants will not differ from each other but an extreme negative may be significantly different from an extreme positive one. In the event, only two of the 
plants have regression coefficients significantly different from some, but not all, of the positives. Such infrequent deviations can be fairly ascribed to chance. With the reservation that only seeds weighing between 10.0 and $19.5 \mathrm{mg}$. have been examined it is therefore justifiable to ignore seed weight when comparing the lectin content of seeds within and between populations.

From table 3 it can be seen that the mean square for differences in lectin titre between-plants and within-years for the Llancynfelyn "low" population is very large and is considerably greater than the mean squares for the other populations. The large size can be attributed

TABLE 3

Analysis of variance of titre of seeds against $\mathrm{A}_{1}$ red-cells, within 5 populations over 3 years

\begin{tabular}{|c|c|c|c|c|c|c|c|c|c|c|}
\hline & \multicolumn{2}{|c|}{$\begin{array}{l}\text { Llancynfelyn } \\
\text { "low"* }\end{array}$} & \multicolumn{2}{|c|}{ Capel Bangor } & \multicolumn{2}{|c|}{ Sutton } & \multicolumn{2}{|c|}{ Marcham } & \multicolumn{2}{|c|}{ Fleam Dyke } \\
\hline & D.F. & MS & D.F. & MS & D.F. & MS & D.F. & MS & D.F. & MS \\
\hline $\begin{array}{l}\text { Between seeds, } \\
\text { within plants }\end{array}$ & 77 & $\mathrm{I} \cdot \mathrm{I} 75$ & 33 & $1 \cdot 162$ & 22 & 0.544 & 15 & $0 \cdot 43^{6}$ & 39 & $03 \cdot 67$ \\
\hline $\begin{array}{l}\text { Between plants, } \\
\text { within years }\end{array}$ & 6 & $16 \cdot 667$ & 4 & 0.865 & 2 & 0.238 & 2 & $0 \cdot 167$ & 4 & $0.35^{1}$ \\
\hline Between years & 2 & $I \cdot 18 I$ & I & $8 \cdot 074$ & 2 & 0.117 & I & $0 \cdot 167$ & I & $0 \cdot 002$ \\
\hline
\end{tabular}

* These entries do not include the plant with 27 chromosomes. The corresponding variances over all the plants at Llancynfelyn "low" read:-

$\begin{array}{cc}\text { D.F. } & \text { MS } \\ 82 & 1 \cdot 122 \\ 7 & 16.013 \\ 2 & 0.222\end{array}$

to the $195^{8}$ sample (the contribution to the sum of squares being $99 \cdot 77$ for 2 degrees of freedom for $195^{8}$ and 0.20 for 4 degrees of freedom for 1959 and 1960 combined). There also seems to be a large difference between years in the Capel Bangor colony. In the Sutton, Marcham and Fleam Dyke colonies on the other hand there are greater differences between the seeds of a single plant than between all the plants in different years. Table 4 reveals that whereas there are population differences in the lectin content of seeds, each population is relatively stable with respect to this character.

When the root-tip chromosomes of 12 seedlings derived from the plant in Llancynfelyn which gave rise to the seeds with the least mean titre in $195^{8}$ were counted, it was found that they all contained 27 chromosomes. The mean titre of the seeds from this plant was significantly different from that of the seeds from the other three plants $\left(t_{(22)}\right.$ for plants I and 2 against 4 is $\left.3.42, \mathrm{P}<0 \cdot 01\right)$. The difference in mean titre between plants $I$ and 2 is not significant $\left(t_{(10)}=0.34\right.$, $\mathrm{P}>0 \cdot 7)$. 
If the Llancynfelyn populations are ignored, the analysis of variance shows that there are significant differences between the other populations for lectin titre in 1959 and 1960 but not in $195^{8}$ and thus it is the

TABLE 4

Analysis of variance of titre of seeds against $\mathrm{A}_{1}$ red-cells, over several populations within 3 years

\begin{tabular}{|c|c|c|c|c|c|c|}
\hline & \multicolumn{2}{|c|}{1958} & \multicolumn{2}{|c|}{ I959 } & \multicolumn{2}{|c|}{ r 960} \\
\hline & D.F. & MS & D.F. & MS & D.F. & MS \\
\hline $\begin{array}{l}\text { Between seeds, within plants } \\
\text { Between plants, within popula- }\end{array}$ & 86 & 0.919 & $5^{8}$ & $\begin{array}{l}1.282 \\
\end{array}$ & 76 & 0.853 \\
\hline $\begin{array}{l}\text { tions } \\
\text { Between populations }\end{array}$ & $\begin{array}{r}11 \\
7\end{array}$ & $\begin{array}{r}2 \cdot 402 \\
12 \cdot 934\end{array}$ & $\begin{array}{l}5 \\
4\end{array}$ & $\begin{array}{r}0 \cdot 406 \\
26 \cdot 769\end{array}$ & $\begin{array}{l}7 \\
4\end{array}$ & $\begin{array}{r}0.128 \\
35 \cdot 641\end{array}$ \\
\hline
\end{tabular}

two Llancynfelyn populations which are making the significant contribution to the mean square in $195^{8}$. The reason for this is far from clear.

\section{THE LECTIN AND THE GERMINATION OF VICIA CRACCA SEEDS}

Leguminous species vary greatly in the readiness with which their seeds germinate. The seeds are usually covered with a hard seed-coat which is impervious to water and gases (Crocker, I948), but the garden pea (Pisum sativum L.), wild tare (Vicia angustifolia Reichard), the runner bean (Phaseolus multiflorus Willd.) and several other species imbibe water through a micropile as soon as they come into contact with it. The cultivated forms have presumably been bred for ease of germination.

Many other leguminous seeds do not have a functional micropile and can be left in contact with water for years without germinating. As soon as the seed-coat is pierced or damaged water can be absorbed and germination begins. Nobbe ( 1890 ) showed that 43 per cent. of an unstated number of Vicia cracca seeds he put into water were still hard after nine years' immersion. As water must pass through the seed-coat before germination can begin the seed must be damaged in some way first. This could happen in several ways. The seed-coat may not be complete, a fault having occurred during the development of the seed, or the seed coat may be complete but be broken by physical force, or bacterial or fungal decay of the seed-coat may be necessary before water can be absorbed. The latter method of induction of germination seems to be widely recognised but several writers can find no definite references to such interaction between seeds and soil micro-organisms (Crocker, r948; Mayer and Poljakoff-Mayber, I963).

Hiltner (I9II) noted that the seed-coats of seeds of several leguminous species were subject to decay by pectin bacteria. It was 
therefore of interest to determine whether soil micro-organisms play a part in the germination of Vicia cracca seeds and whether there is an association between these soil micro-organisms and the lectin in the seeds.

Before beginning the main experiment it was necessary to determine the ability of the Vicia cracca seeds available to germinate spontaneously. Seeds were put on damp filter paper in petri dishes and left to germinate, more water being added when required. After 24 weeks 3 I of 123 seeds from Tomen Castle (Radnorshire) and 3 of roo from Begbroke (Oxford) had germinated. Forty of the seeds which had not germinated were pierced with a needle; all of them germinated at once but one was attacked by fungi.

An experiment was performed to determine whether the anti- $A$ lectin of Vicia cracca would inhibit the growth of soil micro-organisms which decay the seed coats of the plant. Eight free-living soil bacteria were obtained from Dr R. G. Tucker (Department of Chemical Microbiology, Oxford) and two other bacteria were isolated from the soil outside the laboratory and from another soil sample collected in north Oxford in which Vicia cracca was growing. The bacteria isolated from the soil were grown on a minimal medium (Springer, 1956) which had been supplemented in a manner to be described shortly. The other eight bacteria, Pseudomonas master 5940 and 6751, Pseudomonas cm, SK and 7914, Arthrobacter globiformis 8602 and two strains designated J.M.G. and $\mathrm{D}_{2 a b a}$ were grown on " Oxoid" nutrient agar.

\section{(i) Method of isolating soil micro-organisms}

Thirty seeds of Vicia cracca, from the colony at Begbroke, Oxford, were sterilised using the mercuric chloride method of Thornton (1930). These seeds were then put in the soil, the position of each seed being recorded. Three weeks later the seeds were recovered and each was placed on minimal-medium agar to which had been added a homogenate of Vicia cracca seed coats. (Fifty seed coats had been ground up in $250 \mathrm{ml}$. of sterile water in the Waring Blendor. This $250 \mathrm{ml}$. was used as part of the liquid necessary to make I litre of medium. The $p \mathrm{H}$ of the medium was adjusted to approximately $7 \cdot 3$, the $p \mathrm{H}$ of the soil from which the micro-organisms came.)

Numerous fungi and nine bacteria and actinomycetes were obtained by this method. Each of these organisms was subcultured on to minimal medium. Two of the bacteria and three of the fungi did not grow. A second subculture from the original plates on to minimalmedium fortified with biotin showed that this vitamin was a necessary growth factor for the three fungi and that not enough of it was in the agar used, although it appeared to be present in the seed coats of Vicia cracca. The two bacteria did not grow on either medium. Four subcultures of these two bacteria were made on seed coat homogenate minimal-medium before they were tested against Vicia cracca seed 
extracts. The screening was done to isolate organisms which were exacting in their nutritional requirements yet would grow on extracts of the seed coats of Vicia cracca. The fungi, actinomycetes and the other bacteria were, therefore, discarded.

\section{(ii) The action of the lectin on the soil bacteria}

Extracts of Vicia cracca seeds without the seed coat were made in buffered saline at $p \mathrm{H} 7 \cdot 3$. Sorensen's buffer was used as both the constituents, $\mathrm{NaHPO}_{4}$ and $\mathrm{KH}_{2} \mathrm{PO}_{4}$, were present in the minimalmedium (Dunsford and Bowley, 1955). The concentration used was Ioo $\mathrm{mg}$. of seed powder to I $\mathrm{ml}$. of buffered saline.

The extract was divided into four fractions, each fraction being subjected to a different treatment. The control fraction had a titre of 4096 against $A_{1}$ red-cells. The second fraction was heated to $100^{\circ} \mathrm{C}$. for ten minutes. After cooling the titre was o against $A_{1}$ red-cells. The lectin in the third and fourth fractions was adsorbed on to $A_{1}$ red-cells. The agglutinates were washed eight times with buffered saline. The lectin was eluted off at $56^{\circ} \mathrm{C}$. into the same volume of buffered saline as had contained the lectin used for the adsorption. The titre of the eluate was $5^{12}$ against $A_{1}$ red-cells. The eluate of the fourth fraction was heated to $100^{\circ} \mathrm{C}$. for ten minutes and after cooling the titre was found to be o against $A_{1}$ red-cells. Each fraction was sterilised by passing it through a Seitz filter. The purpose of the elution technique was to separate the lectin from the other saline soluble substances of the seeds and thus provide an alternative to the pure lectin preparations obtained by Renkonen (1950).

The tests were performed using the filter disc method reviewed by Skinner (1955). Each strain of the ten micro-organisms was surfaceseeded on to the appropriate agar growth medium in petri dishes. Four pieces of sterile filter paper (Whatman No. I) each I $\mathrm{cm}$. in diameter, were placed on the agar. Three drops of one of the four Vicia cracca extract fractions was put on to one disc. Each of the other three discs was charged with three drops of one of the remaining fractions. It was therefore possible to compare the reaction of all four fractions against the test organism on the same plate.

The bacteria were left to incubate at room temperature $\left(18-22^{\circ} \mathrm{C}\right.$.) for 72 hours. No inhibition of growth was observed with the stock bacteria nor with one of the freshly isolated organisms. The second bacterium was inhibited in growth by the unheated extract and the eluate of Vicia cracca seeds. After three days the zone of inhibition was $4 \mathrm{~mm}$. round the undiluted extract and about $3 \mathrm{~mm}$. round the eluate. Growth around the other two discs was enhanced. The inhibition of growth exerted by the eluate off $A_{1}$ red-cells indicated that the lectin was causing the inhibition and not another substance in the seeds.

This bacterium was tested against two other extracts of Vicia cracca seeds and a purified extract prepared according to the method of 2 G 2 
Renkonen (1950). Inhibition of growth was observed with all three extracts. No quantitative experiments, such as varying the lectin titre of the test solutions, were performed. When tested against seed extracts of Vicia sepium L. no such inhibition of growth was observed.

Saline suspensions of this bacterium were made and it was found that some degree of clumping took place when Vicia cracca seed extracts were added. Small clumps of agglutinates were seen and the running together of individual bacteria to form pairs and triplets was observed under the microscope. Similar small clumps were seen when human anti- $A$ serum was mixed with a saline suspension of the bacterium. No such reaction occurred with human anti-B or seed extracts of Vicia sepium, Lotus corniculatus L. or Trifolium repens L. Isolated clumps of these bacteria gave rise to colonies when plated out on "Oxoid" nutrient agar. The action of Vicia cracca seed extracts therefore appears to be bacteriostatic rather than bactericidal. Thus there is good evidence that the lectin is responsible for the inhibition of growth of this soil bacterium.

\section{(III) Effect of soil bacteria on germination}

The final experiment of the series was to determine whether this bacterium would cause the coats of whole Vicia cracca seeds to decay

TABLE 5

Germination of Vicia cracca seeds after surface-seeding with a soil bacterium known to decay seed coats

\begin{tabular}{|c|c|c|c|}
\hline $\begin{array}{l}\text { Petri } \\
\text { dish }\end{array}$ & $\begin{array}{l}\text { Locality } \\
\text { of seeds }\end{array}$ & $\begin{array}{l}\text { Number } \\
\text { of seeds }\end{array}$ & $\begin{array}{l}\text { Number of seeds } \\
\text { germinated after } \\
\text { six weeks }\end{array}$ \\
\hline \multirow[t]{2}{*}{$\begin{array}{l}\text { I } \\
2 \\
3 \\
4 \\
5\end{array}$} & $\begin{array}{l}\text { Tomen Castle } \\
\text { Tomen Castle } \\
\text { Begbroke Lane } \\
\text { Begbroke Lane } \\
\text { Begbroke Lane }\end{array}$ & $\begin{array}{l}20 \\
20 \\
20 \\
20 \\
20\end{array}$ & $\begin{array}{l}4 \\
4 \\
2 \\
6 \\
3\end{array}$ \\
\hline & Totals . & 100 & 19 \\
\hline & $\begin{array}{l}\text { Control seeds } \\
\text { with no added } \\
\text { bacteria }\end{array}$ & & \\
\hline & $\begin{array}{l}\text { Tomen Castle } \\
\text { Begbroke Lane }\end{array}$ & $\begin{array}{l}20 \\
17\end{array}$ & $\begin{array}{l}0 \\
0\end{array}$ \\
\hline & Totals & 37 & 0 \\
\hline
\end{tabular}

and thus aid germination. Twenty sterile seeds were placed in each of five petri dishes freshly seeded with the bacterium. (These seeds were taken from the 146 left over from the germination experiment previously described.) After three days there was a good growth of bacteria over 
the plate and some bacteria had begun to grow on the outside of many of the seeds.

After ten days several of the seeds began to swell and by $I_{5}$ days six seeds had germinated. Thirteen seeds had germinated 30 days after the beginning of the experiment. Ten of these seedlings were transferred to seedling agar (Thorton, I930; and Nutman, 1946) and they grew healthily. In all, I 9 seeds had germinated by the time, six weeks later, that the agar in the plates had dried out (table 5). Ten of the remaining seeds were pierced and placed on damp filter paper. They began germinating in two days.

\section{DISCUSSION}

The discovery of blood-group-specific plant agglutinins in Leguminose by Renkonen (I 948) and Boyd and Reguera (I949) revived interest in the search for substances in plants and bacteria which would inhibit the agglutination of human red-cells by human iso-antibodies and plant agglutinins. Many attempts have been made to associate blood-group substances in man with human pathogens (Krüpe, I956) without any marked success until Vogel, Pettenkofer and Helmbold (ig6o) and Pettenkofer, Stöss, Helmbold and Vogel (ig62) found that vaccinia virus cross-reacted with human $A$ antigen.

Evidence was presented above that the lectin of Vicia cracca will inhibit the growth of a soil micro-organism known to metabolise the seed coats of this species. It is unlikely that this is the sole function of the lectin for Mäkelä (1957) has shown how restricted is the distribution of such substances even in Leguminose. The only other Vicia species known to contain an anti- $A$ like lectin are all closely related to Vicia cracca (Hegi, I 924). The occurrence of an anti- $\mathcal{N}$ like lectin in the seeds of Vicia graminia Sm. (Ottensooser and Silberschmidt, I953) is unique for the genus.

The presence of the lectin in Vicia cracca is probably determined by a dominant gene (Rousi, I96I) but the evidence shows that the expression of this gene, in terms of lectin titre, varies from population to population. It has been demonstrated that the titre of a seed extract against $A_{1}$ or $B$ red-cells is independent of the weight of the seed (Jones, I964). Thus natural selection appears to be favouring a stable phenotype in a population for a biochemical character which is expressible in activity per seed rather than activity per unit weight of seed. This suggests that there may be an optimum lectin activity for all the seeds within a particular population and this optimum varies from population to population. As the populations are stable from year to year with respect to mean titre it appears that these populations are approaching equilibrium.

Evidence has been obtained supporting Punin's suggestion (1952) that plant agglutinins may be "antibodies" against soil microorganisms. If this hypothesis is correct, then, in a given type of soil, 
selection by pathogenic soil micro-organisms would rapidly ensure that only the plants resistant to attack would grow, presumably because they contain enough of the agglutinin to prevent the pathogen from killing the seedling. Springer (1958), using artificial membranes, has demonstrated that plant agglutinins are non-dialisable polysaccharides. There is some evidence (Jones, unpublished observations) that the agglutinins of Vicia cracca, Viccia sepium, Ulex europeaus L. and Lathyrus pratensis L. are non-dialisable in vivo. In these circumstances the lectin could immobilise a pathogen only after it has entered the plant tissues. Without further work it is not possible to say whether differences in the soil micro-organism environment are responsible for the different optimum levels of lectin in the seeds in the populations studied.

\section{SUMMARY}

I. In I 2 populations of Vicia cracca L. in Britain all but one of the plants tested gave rise to seeds containing 28 chromosomes.

2. Seeds with 27 chromosomes, obtained from a plant growing near Llancynfelyn, Cardiganshire, contained significantly less lectin than other seeds from the same population. The mean titre of the lectin in the seeds of the remaining plants in this colony was significantly lower than that of the other populations tested.

3. Analysis of variance of lectin titre with respect to years and populations, revealed that the mean titre for any one population remained remarkably stable from year to year. There were some consistent significant differences in mean titre of seeds between several of the populations.

4. The anti-A lectin of Vicia cracca was shown to inhibit the growth of a soil bacterium which caused the seed coats of the plant to decay. This bacterium was agglutinated (small clumps were observed) by the lectin and by human anti- $A$ sera. The mechanism of inhibition of growth appeared to be bacteriostatic rather than bactericidal.

5. It is possible that such soil bacteria aid the germination of hard coated seeds. The lectin may then prevent invasion of the young seedling tissues. It is emphasised that this may not be the only, nor indeed the prime function of lectins.

Acknowledgments.-I am grateful to Prof. E. B. Ford, F.R.S., for his help and guidance during the course of the work. I also thank Prof. K. Mather, F.R.S., and Dr J. L. Jinks for their advice on the statistical analyses and for their comments on the manuscript. The work was carried out in the Genetic Laboratories, Department of Zoology, Oxford, while in receipt of a Medical Research Council scholarship for training in research methods.

\section{REFERENCES}

BOYD, W. C., AND REGUERA, R. M. I949. Haemagglutinating substances for human red-cells in various plants. $\mathcal{F}$. Immunol., 62, 333-339.

BOYD, w. C., AND HOOKER, S. B. 1939. The influence of molecular weight on the proportion of antibody to antigen in precipitates. II. A statistical examination of available data, including some unpublished. F. gen. Physiol., 22, 281-292. 
Grocker, w. I948. Growth of Plants. Reinhold Publ. Co., New York.

DUNSFORD, I., AND BOWLEY, C. C. 1955. Techniques in Blood Grouping. Oliver and Boyd, Edinburgh.

HEGI, G. I924. Illustrierte Flora von Mittel-Europa. Vol. 4, part 3. Lehmanns, München.

hILTNER, L. IgII. Die Prüfung des Saatgutes auf Frische und Gesundheit, in Verhandl. II Internat. Konfer. $f$. Samenpriifung in Münster und Wageningen (1910).

JONES, D. A. I961. Lectins in old seeds. Vox. Sang., 6, 502-505.

JONES, D. A. Ig64. The lectin in the seeds of Vicia cracca L. I. The relationship between the lectin and the anti-human-red-cell agglutinin. (In preparation.)

KRÜPE, м. 1956. Blutgruppenspezifische Pflanzliche Eiweiskörper (Phytagglutinine). Enke, Stuttgart.

MÄкELÄ, о. 1957. Studies in hæmagglutinins of Leguminose seeds. Ann. Med. exp Fenn., 35, Suppl. I I, I-I 33 .

mayer, A. M., AND POLJAKoff-Mayber, A. 1963. The Germination of Seeds. Pergamon, London.

NoBbe, F. I8go. Über die Hartschligkeit von Samen. Abhandl. Naturw. (Bremen), I89o, 289-294.

NUTMAN, P. s. 1946. Variation within strains of clover nodule bacteria in the size of nodule produced and in the effectivity of the symbiosis. 7. Bact., $5^{I}, 4^{1 \mathrm{I}-432}$.

otTenSOOSER, F., AND SILBERSChMIDT, K. 1955. Hæmagglutinin anti- $\mathcal{N}$ in plant seeds. Nature, $172,9^{14} 4$ only.

PetTenkofer, H. J., STÖss, B., Helmbold, W., AND vogel, F. 1962. Alleged causes of the present day world distribution of the human $\mathrm{ABO}$ blood groups. Nature, $193,444-446$.

puniN, w. 1 952 . Über den Wirkungsmechanisms der pflanzlichen anti-O-agglutinine. Z. Naturf., 76, 48-5o.

RENKONEN, K. O. I948. Studies on hæmagglutinins present in seeds of some representatives of the family Leguminose. Ann. Med. exp. Fenn., 26, 66-72.

RENKONEN, K. O. I950. Studies on the nature of hæmagglutinins present in seeds. Ann. Med. exp. Fenn., 28, 45-51.

renkonen, K. o., AND therman, e. 1952. Chromosome number and the anti- $A$ agglutinins in seeds of Vicia cracca. Ann. Med. exp. Fenn., 30, 327-328.

Rousi, A. I961. Cytotaxonomical studies on Vicia cracca L. and V. tenuifolia Roth. I. Chromosome numbers and karyotype evolution. Hereditas, 47, 8I-I Io.

skinner, F. A. 1955. Antibiotics, in Modern Methods of Plant Analysis. Vol. 3. Edited by K. Paech and M. V. Tracey. Springer, Berlin.

SPRINGER, G. F. 1956. Inhibition of blood group agglutinins by substances occurring in plants. 7. Immunol., 76, 399-407.

SPRINGER, G. F. 1958. Blood group active substances of plant origin, in Chemistry and Biology of Mucopolysaccharides. Churchill, London.

THoRnton, H. G. I930. The early development of the root-nodule of lucerne (Medicago sativa L.). Ann. Bot., 44, 385-392.

vogel, f., PETtenkofer, H. J., AND helmbold, w. Ig6o. Über die Populationsgenetik der ABO-Blutgruppen. Acta Genet., Io, 268-294. 